\title{
InhA, a target of the antituberculous drug isoniazid, is involved in a mycobacterial fatty acid elongation system, FAS-II
}

\author{
Hedia Marrakchi, Gilbert Lanéelle and Annaïk Quémard \\ Author for correspondence: A. Quémard. Tel: +33 5611755 76. Fax: +33 561175994. \\ e-mail: annaik@ipbs.fr
}

Institut de Pharmacologie et de Biologie Structurale, Centre National de la Recherche Scientifique, 205 route de Narbonne 31077 Toulouse cedex, France

\begin{abstract}
Most drug-resistant clinical isolates of the tubercle bacillus are resistant to isoniazid, a first-line antituberculous drug. This antibiotic was shown to act on Mycobacterium tuberculosis by inhibiting a 2-trans-enoyl-acyl carrier protein reductase, called InhA. However, the exact role played by InhA in mycobacteria remained unclear. A mycobacterial enzyme fraction containing InhA was isolated. It displays a long-chain fatty acid elongation activity with the characteristic properties described for the FAS-II (fatty acid synthetase II) system. Inhibition of this activity by InhA inhibitors, namely isoniazid, hexadecynoyl-CoA or octadecynoyl-CoA, showed that InhA belongs to the FAS-II system. Moreover, the InhA inhibitors also blocked the biosynthesis of mycolic acids, which are major lipids of the mycobacterial envelope. The data strongly suggest that isoniazid acts on the mycobacterial cell wall by preventing the FAS-II system from producing long-chain fatty acid precursors for mycolic acid biosynthesis.
\end{abstract}

Keywords: InhA, fatty acid synthetase II, mycolic acid biosynthesis, isoniazid target, Mycobacterium

\section{INTRODUCTION}

Tuberculosis is still a major cause of death from an infectious agent in developing countries, and constitutes a serious threat in large cities of industrialized countries (Snider et al., 1994). The resurgence of tuberculosis during the last decade has been partly caused by the emergence of multi-drug resistant Koch bacilli.

Most drug-resistant Mycobacterium tuberculosis clinical isolates are resistant to isoniazid (INH), which is a first-line drug used to treat tuberculosis (World Health Organization, 1997). Recent investigations have shown that the InhA protein produced by this bacterium is a target of INH (Banerjee et al., 1994; Dessen et al., 1995; Quémard et al., 1995, 1996; Zabinski \& Blanchard, 1997; Rozwarski et al., 1998). Mutations in the inhA gene, or in its putative promoter region, confer INH resistance to laboratory isolates of Mycobacterium bovis or Mycobacterium smegmatis (Banerjee et al., 1994) and are probably responsible for the INH-resistant pheno-

\footnotetext{
Abbreviations: ACP, acyl carrier protein; FAS, fatty acid synthetase; FES, fatty acid elongation system; INH, isoniazid (isonicotinic acid hydrazide); NE, 2-(2,3-naphthalimino)ethyl; NE-OTf, 2-(2,3-naphthalimino)ethyl trifluoromethanesulphonate; $p$ CMS, $p$-chloromercuriphenylsulphonic acid.
}

type of a significant part of $M$. tuberculosis clinical isolates (Kapur et al., 1995; Ristow et al., 1995; Musser et al., 1996; Basso et al., 1998). The inhA gene product is an NADH-dependent enoyl-acyl carrier protein reductase, which catalyses the reduction of 2-transenoyl chains possessing at least 12 carbon atoms (Quémard et al., 1995; Dessen et al., 1995). This enzymic activity corresponds to the last step of each two-carbonelongation round in the fatty acid biosynthesis pathway. As data presented by Banerjee et al. (1994) strongly suggest that the inhA gene is involved in the production of very-long-chain fatty acids, mycolic acids, it is reasonable to imagine that InhA is part of a fatty acid elongation system whose products represent intermediates in the biosynthesis of these unusual molecules.

Mycolic acids are $\alpha$-branched $\beta$-hydroxylated fatty acids, and constitute major and specific components of the mycobacteria and related genera. They are believed to play an essential role in mycobacterial-envelope architecture, forming the junction between the capsule and the cell-wall skeleton, where they are covalently bound (Daffé \& Draper, 1998). Inhibition of mycolic acid biosynthesis is the first event detected in M. tuberculosis treated with INH (Takayama et al., 1972), and numerous observations indicate that INH treatment causes 
extensive damage to the envelope organization, such as loss of the acid-fast property (Middlebrook, 1952), release of abnormal amounts of proteins into the culture medium and altered ultrastructure (Bardou et al., 1996).

Recently, we described a gene cluster, $c m a A-D$, involved in the introduction of oxygenated functions and cyclopropanes into the main chain of mycolic acids of the M. tuberculosis complex (Dubnau et al., 1997, 1998). However, not much information is available on the formation of the main chain, called the meromycolic chain (Daffé \& Draper, 1998; Lanéelle, 1989). It was postulated in the literature as early as 1982 (Winder, 1982; Takayama \& Qureshi, 1984) that at least two enzyme systems are involved in the synthesis of verylong-chain precursors of mycolic acids, and this hypothesis was built up by putting together data obtained independently over the last few decades: (i) the identification, in M. smegmatis, of two fatty acid biosynthesis systems called FAS-I (fatty acid synthetase I) and FAS-II, FAS-I catalysing de novo synthesis and FAS-II producing unusually long fatty acids (Bloch, 1977); (ii) the fact that a crude soluble extract of $M$. tuberculosis can elongate palmitate, a FAS-II primer, to give up to $\mathrm{C}_{32}$-saturated fatty acids and over $\mathrm{C}_{40}$-monounsaturated fatty acids (Qureshi et al., 1984); (iii) the demonstration that InhA, which catalyses the last step of fatty acid elongation, is the target of INH, an efficient inhibitor of mycolic acid biosynthesis (Banerjee et al., 1994; Quémard et al., 1995, 1996).

The above convergent data suggest that a FAS-IIlike system could synthesize long-chain precursors of mycolic acids, but no experimental results directly link the above set of data to confirm this hypothesis. In this paper, we report evidence that InhA is part of the FASII system, and that the elongation complex is probably involved in the synthesis of mycolic acids.

\section{METHODS}

Cultures. M. smegmatis strain $\mathrm{mc}^{2} 155$ was grown on Middlebrook $7 \mathrm{H} 9$ broth supplemented with $0 \cdot 2 \%(\mathrm{v} / \mathrm{v})$ glycerol. Culture growth was stopped at late exponential phase and cells were harvested by centrifugation.

Preparation of protein extracts containing FAS-I and FAS-II systems. The bacterial pellet was washed and suspended in $100 \mathrm{mM}$ potassium phosphate buffer, pH 7·2, containing $1 \mathrm{mM}$ DTT and $1 \mathrm{mM}$ EDTA. The suspension was sonicated with a Branson Sonifier Cell Disrupter B15 (microtip 3, 60\% duty cycle, four times with $5 \mathrm{~s}$ on, $40 \mathrm{~s}$ off). The disrupted cells were centrifuged at $43500 \mathrm{~g}$ for $30 \mathrm{~min}$ to remove cell debris. The FAS-I and FAS-II systems were prepared from the crude supernatant obtained by centrifugation and separated as previously described (Odriozola et al., 1977), except that the $35-80 \%(\mathrm{w} / \mathrm{v})\left(\mathrm{NH}_{4}\right)_{2} \mathrm{SO}_{4}$ precipitate was dissolved in $100 \mathrm{mM}$ potassium phosphate buffer containing $1 \mathrm{mM}$ DTT and $1 \mathrm{mM}$ EDTA, and applied to a Sephadex G-200 (Pharmacia) column. The elution profile at $280 \mathrm{~nm}$ was similar to that obtained by Odriozola et al. (1977). Fraction I corresponded to the first peak (elution volume from $24 \cdot 2$ to $33 \mathrm{ml}$ for a column of $16 \times 370 \mathrm{~mm}$ ), and fraction II to the first part of the second peak (elution volume from 39.6 to $48.4 \mathrm{ml}$ ). Protein fractions were concentrated either by $80 \%(\mathrm{w} / \mathrm{v})$
$\left(\mathrm{NH}_{4}\right)_{2} \mathrm{SO}_{4}$ precipitation or in an Amicon ultrafiltration unit (cut off, $10 \mathrm{kDa}$ ); similar results were obtained using either method.

Preparation of cell-wall extracts. The bacterial pellet was washed and suspended in $50 \mathrm{mM}$ potassium phosphate buffer, $\mathrm{pH} 7 \cdot 0$, containing $3 \mathrm{mM} \beta$-mercaptoethanol. The cells were disrupted by two passages through a cell disrupter (Constant Systems) at $0.4 \mathrm{kbar}$. The suspension was centrifuged at $3000 \mathrm{~g}$ for $20 \mathrm{~min}$ and the upper-layer material, corresponding to cellwall extract (Lacave et al., 1990), was taken off and homogenized in $200 \mathrm{mM}$ potassium phosphate buffer, $\mathrm{pH} 7 \cdot 0$.

Protein assays. Protein assays were performed on protein extracts or on whole bacteria by the Bio-Rad DC method (Bio$\mathrm{Rad}$ ), after boiling samples for $10 \mathrm{~min}$ in $0.5 \mathrm{M} \mathrm{NaOH}$ to solubilize insoluble proteins.

Western blots. Fifteen percent (w/v) polyacrylamide-SDS gels were either stained with Coomassie blue or the proteins transferred onto a nitrocellulose membrane. Polyclonal rabbit anti-InhA antibodies were used for Western blot analyses. Antibodies against pure M. tuberculosis $\mathrm{H} 37 \mathrm{Rv}$ InhA protein were prepared (Eurogentec), and purified on an affinity $\mathrm{CNBr}-$ activated Sepharose 4B column (Pharmacia) covalently coupled with pure InhA protein. Antigen-antibody interactions were revealed by a colorimetric reaction using alkaline phosphatase conjugated to mouse anti-rabbit IgG.

Fatty acid elongation assays. FAS-type assays: The de novo FAS-I-type assay was based on the previously described assay (Odriozola \& Bloch, 1977) : $300 \mu \mathrm{M}$ acetyl-CoA, $20 \mu \mathrm{M}$ $\left[2-{ }^{14} \mathrm{C}\right]$ malonyl-CoA (specific radioactivity, $444 \mathrm{kBq}_{\mu} \mathrm{mol}^{-1}$ ), $100 \mu \mathrm{M}$ CoA, $100 \mu \mathrm{M}$ NADH, $100 \mu \mathrm{M}$ NADPH, $1 \mu \mathrm{M}$ FMN, $5 \mathrm{mM}$ DTT, $100 \mathrm{mM}$ potassium phosphate buffer, $\mathrm{pH} 7 \cdot 2$, and $200 \mu \mathrm{g}$ proteins [or $10 \mu \mathrm{g}$ for comparison with FES (fatty acid elongation system) assays], in a total volume of $500 \mu \mathrm{l}$. Reactions were incubated for $1 \mathrm{~h}$ at $37^{\circ} \mathrm{C}$ with shaking at 200 r.p.m.

The standard FAS-II-type elongation assay was based on the previously described assay (Odriozola et al., 1977): $50 \mu \mathrm{M}$ palmitoyl-CoA, $20 \mu \mathrm{M}$ [2- $\left.{ }^{14} \mathrm{C}\right]$ malonyl-CoA (specific radio-

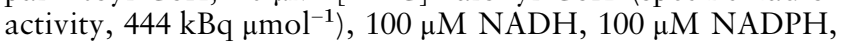
$40 \mu \mathrm{M}$ ACP (acyl carrier protein), $1 \mathrm{mM}$ DTT, $100 \mathrm{mM}$ potassium phosphate buffer, $\mathrm{pH} 7 \cdot 2$, and 100 or $200 \mu \mathrm{g}$ proteins (or $10 \mu \mathrm{g}$ for comparison with FES assays), in a total volume of $500 \mu \mathrm{l}$. Reactions were incubated for $1 \mathrm{~h}$ at $37^{\circ} \mathrm{C}$, with shaking at 200 r.p.m. When indicated, $\left[2-{ }^{14} \mathrm{C}\right]$ malonylCoA was replaced with $\left[1-{ }^{14} \mathrm{C}\right]$ acetyl-CoA at the same concentration, and the same specific radioactivity.

2-Hexadecynoyl-CoA and 2-octadecynoyl-CoA (C. Vilchèzes \& R. Bittman, unpublished synthesis method) were tested at $43 \mu \mathrm{M}$ either in FAS-I or in FAS-II standard assays. $p$ Chloromercuriphenylsulphonic acid ( $p$ CMS) was tested at $1 \mathrm{mM}$ on standard reaction mixtures, but in the absence of DTT (which is known to react with $p$ CMS) in both the controls and the assays. For the assays in the presence of INH, standard reaction mixtures, without palmitoyl-CoA, malonylCoA and ACP for FAS-II assays, or without acetyl-CoA, malonyl-CoA, CoA and FMN for FAS-I assays, were first preincubated for $3 \mathrm{~h}$ at $25^{\circ} \mathrm{C}$ with gentle shaking, in the presence of $100 \mu \mathrm{M}$ INH and $2 \mu \mathrm{M} \mathrm{MnCl}_{2}$. The control experiments were treated in the same way, except that INH was omitted. Reactions were started, after preincubation, by the addition of the missing reagents and incubated for $1 \mathrm{~h}$ at $37^{\circ} \mathrm{C}$.

FES-type assays: FES-I and FES-II elongation assays were based on previously described assays (Kikuchi \& Kusaka, 
1982; Shimakata et al., 1977). Reactions were performed in a total volume of $500 \mu \mathrm{l}$, with $1 \mathrm{mM}$ DTT, $100 \mathrm{mM}$ potassium phosphate buffer, $\mathrm{pH} 7 \cdot 2$, protein extract at $20 \mu \mathrm{g} \mathrm{ml}^{-1}$, and, for FES-I assays, $50 \mu \mathrm{M}$ octanoyl-CoA, $75 \mu \mathrm{M}\left[1-{ }^{14} \mathrm{C}\right]$ acetylCoA (specific radioactivity, $444 \mathrm{kBq} \mu \mathrm{mol}^{-1}$ ), $200 \mu \mathrm{M} \mathrm{NADH}$, or, for FES-II assays, $50 \mu \mathrm{M}$ stearoyl-CoA, $20 \mu \mathrm{M}$ [2-

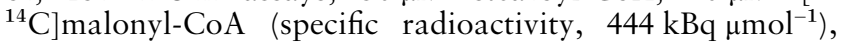
$100 \mu \mathrm{M}$ NADH, $100 \mu \mathrm{M}$ NADPH and $20 \mu \mathrm{M}$ FMN. Reactions were incubated for $1 \mathrm{~h}$ at $37^{\circ} \mathrm{C}$ with shaking at 200 r.p.m.

Reactions were stopped by the addition of 1 vol. of $10 \%$ (w/v) $\mathrm{KOH}$ in methanol/benzene $(8: 2, \mathrm{v} / \mathrm{v})$ and saponification was performed at $80^{\circ} \mathrm{C}$ either for $30 \mathrm{~min}$ for reactions with fraction I or fraction II or overnight for reactions with cellwall extract.

Mycolic acid biosynthesis assays. For assays with whole bacteria, an aliquot of the bacterial suspension used to prepare the cell-wall extract was removed before cell disruption (see above). Mycolic acid biosynthesis was tested on cell-wall extracts or on whole bacteria in reactions with 100-125 $\mu \mathrm{g}$ protein $\mathrm{ml}^{-1}$ in $100 \mathrm{mM}$ potassium phosphate buffer, $\mathrm{pH} 7 \cdot 0$, in a total volume of $1.5 \mathrm{ml}$. INH was tested at $100 \mu \mathrm{M}$ in the presence of $10 \mu \mathrm{M} \mathrm{MnCl}_{2}$, with a $3 \mathrm{~h}$ preincubation at $25^{\circ} \mathrm{C}$ in the reaction mixture. Octadecynoyl-CoA was tested at $43 \mu \mathrm{M}$, with or without a $30 \mathrm{~min}$ preincubation at $25^{\circ} \mathrm{C}$. Reactions were started by the addition of $50 \mu \mathrm{M}\left[1-{ }^{14} \mathrm{C}\right]$ acetate (specific activity, $2 \cdot 11 \mathrm{MBq} \mu \mathrm{mol}^{-1}$ ) and incubated for $1 \mathrm{~h}$ at $37^{\circ} \mathrm{C}$ with shaking at 160 r.p.m. Reactions were stopped by the addition of $1 \mathrm{vol} .10 \%(\mathrm{w} / \mathrm{v}) \mathrm{KOH}$ in methanol/benzene $(8: 2, \mathrm{v} / \mathrm{v})$, and saponification performed overnight at $80{ }^{\circ} \mathrm{C}$.

Analysis of the reaction products. Lipids were extracted from the reaction mixtures with diethyl ether. Total lipid labelling was measured by scintillation counting on an aliquot of each extract. For TLC analysis, fatty acids were methylated with diazomethane. Samples were analysed on Silicagel G60 plates eluted with dichloromethane. Radiolabelling of TLCseparated components was measured by a radioscanner (Automatic TLC linear analyser LB 2832; Berthold), and lipids were revealed by spraying with $20 \%$ (v/v) sulphuric acid and charring.

To determine the chain lengths of the fatty acids produced by fraction II, the alkali-labile lipid extracts of five standard FASII reactions were pooled. To be able to detect the fatty acids by spectrophotometry, 2-(2,3-naphthalimino)ethyl (NE) ester derivatives were prepared by modifying the method of Yasaka et al. (1990), as follows. Known amounts of unlabelled fatty acid standards were added to the radiolabelled lipids to facilitate the detection of the fatty esters separated by HPLC and to measure the yield of derivatization of each fatty acid in the mixture. Eighty nanomoles of total fatty acids were solubilized in $4.8 \mathrm{ml} \mathrm{CHCl}_{3}$ and the following reagents were added: $800 \mu \mathrm{l} 18$-Crown- 6 ( $1 \mathrm{mM}$ in $\left.\mathrm{CHCl}_{3}\right), 40 \mathrm{mg}$ anhydrous potassium fluoride, and, after vortexing, $80 \mu \mathrm{l} 2-(2,3-$ naphthalimino)ethyl trifluoromethanesulphonate (NE-OTf; Pierce) ( $1 \mathrm{mM}$ in acetonitrile). Reactions were incubated in sealed tubes overnight at room temperature with vigorous shaking. After the reaction, fatty acyl-NE esters were separated from the small amount of low- $R_{F}$ radiolabelled compounds (observed on thin-layer silica gels) on a Sep-pak silica cartridge (Waters). Reaction mixtures were dried under nitrogen and loaded onto the cartridge in petroleum ether/ dichloromethane $(7: 3, \mathrm{v} / \mathrm{v})$; fatty acyl-NE esters were eluted with the same solvent mixture, nitrogen-dried, and dissolved in acetonitrile. Each sample was analysed by HPLC on a Chromosorb 3ODS2 column (Chromato-Sud) eluted at $1 \mathrm{ml}$ $\mathrm{min}^{-1}$ with the following conditions: a 10 min gradient from
90 to $100 \%(\mathrm{v} / \mathrm{v}) \mathrm{CH}_{3} \mathrm{OH}$ in water, followed by a 50 min step at $100 \%(\mathrm{v} / \mathrm{v}) \mathrm{CH}_{3} \mathrm{OH}$. Acyl-NE derivatives were detected at $259 \mathrm{~nm}$ and collected separately. The quantity of acyl-NE in each fraction was calculated by measuring absorbance at $259 \mathrm{~nm}$ in $\mathrm{CH}_{3} \mathrm{OH}\left(\varepsilon_{259}=62000 \mathrm{M}^{-1} \mathrm{~cm}^{-1}\right)$, and radioactivity was measured by scintillation counting in Lipoluma scintillant (Lumac, LSC). The amount of radioactivity of each acyl-NE compound was corrected for the yield of derivatization obtained for the standards.

\section{RESULTS}

\section{Isolation of an enzyme fraction containing InhA}

FASs have been classified into three types (I, II and III; Harwood, 1986). The type I synthetases are highmolecular-mass multifunctional proteins containing covalently bound ACP and occur mainly in animal cells and yeast; the type II synthetases consist of several monofunctional enzymes and are present in plants and bacteria. Both type I and type II systems catalyse de novo fatty acid synthesis, whereas the type III synthetases, which are found in animals and plants, elongate preformed acyl chains to give long- or very-long-chain molecules (Harwood, 1986). Mycobacteria are very unusual in that they contain several types of fatty acid synthetase. Four different straight-chain fatty acid biosynthesis systems have been described in M. smegmatis by two independent groups: FAS-I, which is a type I synthetase responsible for the synthesis of mediumlength fatty acids $\left(\mathrm{C}_{16}, \mathrm{C}_{24}\right)$ (Bloch, 1977), and FAS-II (Bloch, 1977), FES-I (Shimakata et al., 1977) and FES-II (Kikuchi \& Kusaka, 1982), which are elongation systems composed of monofunctional enzymes, and which resemble the type III rather than the type II synthetases. The enzyme system which was the most likely to contain

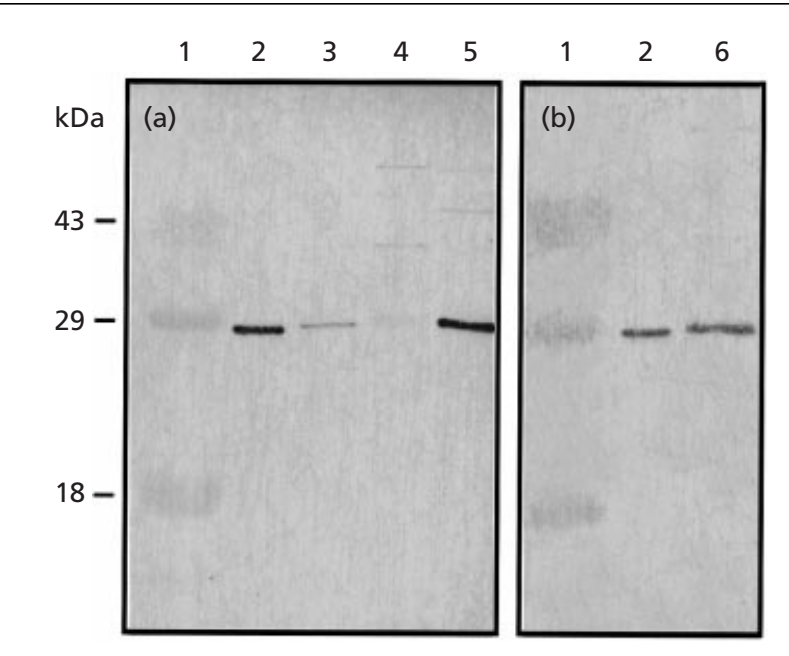

Fig. 1. Western blots using anti-InhA antibodies. (a) Analysis of fraction I and fraction II, (b) analysis of cell-wall extract. Lanes: 1, pre-stained molecular standards; 2, pure InhA; 3, total sonication extract; 4, fraction I; 5 , fraction II; 6 , cell-wall extract. $25 \mu \mathrm{g}$ protein from each sample and $5 \mathrm{ng}$ pure InhA were used for SDS-PAGE. Anti-InhA antibodies were previously purified on an affinity column. 
Table 1. FAS-I and FAS-II-type enzymic assays with fraction I and fraction II

Two hundred micrograms of proteins were used for reactions with fraction I or fraction II. Assays were repeated in two independent experiments, and representative results are shown.

\begin{tabular}{|c|c|c|c|c|c|c|}
\hline \multirow{4}{*}{$\begin{array}{r}\text { Elongation unit... } \\
\text { Fraction... }\end{array}$} & \multicolumn{6}{|c|}{ Radioactivity (d.p.m.) } \\
\hline & \multicolumn{4}{|c|}{ FAS-II reaction* } & \multirow{2}{*}{\multicolumn{2}{|c|}{$\begin{array}{c}\text { FAS-I reaction } \dagger \\
{\left[2-{ }^{14} \mathrm{C}\right] \text { Malonyl-CoA }}\end{array}$}} \\
\hline & \multicolumn{2}{|c|}{$\left[2-{ }^{14} \mathrm{C}\right]$ Malonyl-CoA } & \multicolumn{2}{|c|}{$\left[1-{ }^{14} \mathrm{C}\right]$ Acetyl-CoA } & & \\
\hline & I & II & I & II & I & II \\
\hline & 3059 & 32152 & 787 & 1740 & 30986 & 3206 \\
\hline
\end{tabular}

*Primer was palmitoyl-CoA, cofactor ACP.

†Primer was acetyl-CoA, cofactor FMN.

InhA was the FAS-II system, since it shares properties with the InhA protein, such as its specificity for substrates bearing at least 12 carbons, its preference for around 16-carbon molecules, and its ACP dependence (Bloch, 1977; Quémard et al., 1995). Thus, we first isolated from M. smegmatis $\mathrm{mc}^{2} 155$ a protein fraction containing FAS-II to test for the presence of InhA. FASI and FAS-II, which are both present in the 35-80\% $(\mathrm{w} / \mathrm{v})$ ammonium sulphate precipitate, were separated on a Sephadex G-200 column. Two pools of fractions, called fraction I and fraction II, assumed to contain the FAS-I and the FAS-II systems, respectively (Odriozola et al., 1977), were analysed by Western blotting, using polyclonal rabbit anti-InhA antibodies (Fig. 1a). The total protein extract obtained after sonication showed a faint band staining for InhA, while fraction II appeared highly enriched in this protein. In contrast, no positive signal corresponding to InhA was detected in fraction I.

\section{Fatty acid elongation activity in the InhA-containing fraction}

To confirm that fractions I and II contain FAS-I and FAS-II systems, respectively, these fractions were then tested for elongation activity (Table 1). Indeed, the optimum reaction conditions for fraction II corresponded to those described for FAS-II (Odriozola et al., 1977): elongation of palmitoyl-CoA by [2$\left.{ }^{14} \mathrm{C}\right]$ malonyl-CoA, in the presence of ACP. Omission of ACP resulted in a decrease of $85 \%( \pm 11 \%)$ of radioactive incorporation into total lipids, and a complete inhibition of fatty acid biosynthesis. In FAS-I-type reactions, only fraction I led to strong labelling of alkalilabile lipids (Table 1). Furthermore, by TLC and radioscanning (see below), fraction II displayed no significant fatty acid biosynthesis activity under the optimum reaction conditions described for the elongation systems FES-I (primer, octanoyl-CoA; elongation unit, $\left[{ }^{14} \mathrm{C}\right]$ acetyl-CoA; Shimakata et al., 1977) and FES-II (primer, stearoyl-CoA; elongation unit, $\left[{ }^{14} \mathrm{C}\right]$ malonyl-CoA ; cofactor, FMN ; Kikuchi \& Kusaka, 1982).

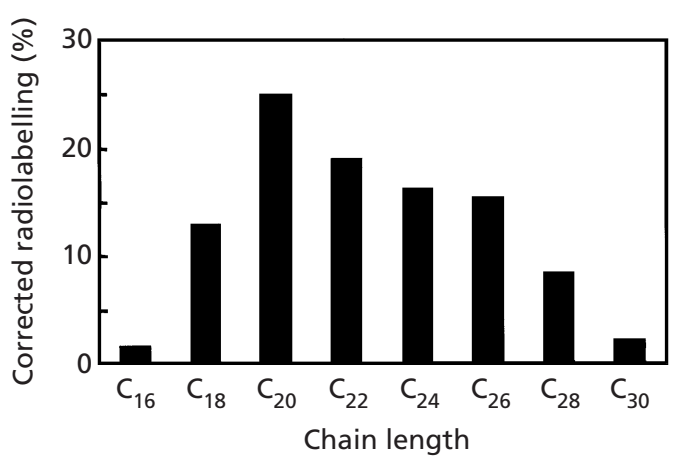

Fig. 2. Chain lengths of the fatty acids synthesized by fraction II. Acyl-NE derivatives of the radiolabelled fatty acids produced by fraction II in FAS-II assays were prepared and separated by HPLC. The percentage of labelling of each fatty acid relative to the total radioactivity of all fatty acids is displayed. Radioactivity values varied from $2 \times 10^{3}$ to $3 \times 10^{4}$ d.p.m.

To characterize the compounds radiolabelled by fraction II in a standard FAS-II-type assay, lipids extracted after alkaline treatment of the reaction medium were first analysed by TLC, argentation-TLC and radioscanning. Most of the radioactivity coming from [2$\left.{ }^{14} \mathrm{C}\right]$ malonyl-CoA was incorporated into saturated, straight-chain fatty acids (data not shown). The chain lengths of the labelled fatty acids were then determined by HPLC. Highly fluorescent NE ester derivatives of the fatty acids were prepared from NE-OTf. Although the method has been optimized to improve the derivatization yield of long-chain fatty acids, which are less soluble, the yield sharply decreased with increasing chain length. To solve this problem, derivatization was performed with internal standards, i.e. in the presence of known amounts of $\mathrm{C}_{16}-\mathrm{C}_{30}$ saturated fatty acids, and the derivatization yield was calculated for each chain length (see Methods). The corrected values of radioactivity corresponding to each HPLC peak showed that fraction II synthesizes saturated fatty acids from $\mathrm{C}_{18}$ to $\mathrm{C}_{30}$ (Fig. 2). The major products are $\mathrm{C}_{18}-\mathrm{C}_{26}$ fatty acids. The 


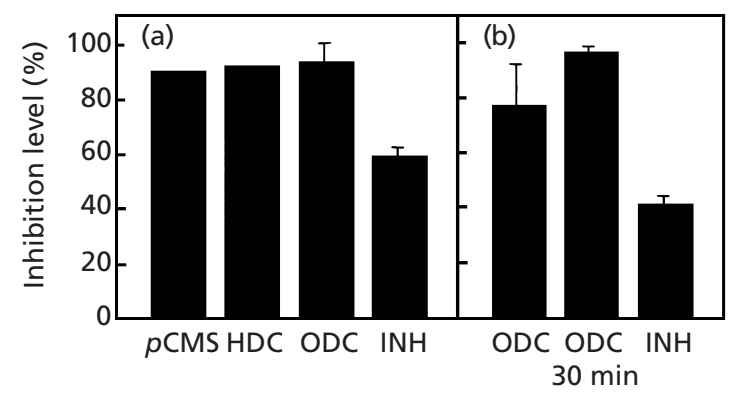

Fig. 3. Effect of inhibitors on fraction II elongation activity or on mycolic acid biosynthesis. Inhibitors were tested in FAS-II standard assays (a) or in mycolic acid biosynthesis assays (b). For testing $p C M S$, DTT was omitted. pCMS, 2-hexadecynoyl-CoA (HDC) and 2-octadecynoyl-COA (ODC) were tested either without preincubation or with a 30 min preincubation in the presence of the protein extract; INH was preincubated for $3 \mathrm{~h}$ in the presence of the protein extract (see Methods). Inhibition levels (\%) were calculated as labelling ratios of assays versus control experiments performed in parallel in the absence of inhibitor. Means and standard deviations of at least two independent experiments are displayed.

weak labelling of $\mathrm{C}_{16}-\mathrm{NE}$ is probably due to the contamination of commercial palmitoyl-CoA by myristoyl-CoA $\left(\mathrm{C}_{14}\right)$, which can also be used as primer by FAS-II.

Thus fraction II, which contains the InhA protein, exhibits the same properties as those described for the FAS-II system (Bloch, 1977), i.e. an ACP-dependent enzymic activity which promotes elongation of palmitoyl-CoA into $\mathrm{C}_{18}-\mathrm{C}_{30}$ fatty acids, using malonyl$\mathrm{CoA}$ as the elongation unit.

\section{Is InhA involved in the elongation activity of FAS-II?}

The effects of inhibitors on the incorporation of radioactivity into saturated fatty acids were analysed by scintillation counting and radioscanning on TLC. As expected, $p$ CMS, which is a thiol-selective reagent, strongly inhibited both the elongation activity of fraction II (by $90 \%$, Fig. 3a) and the synthesis activity of fraction I (by $71 \pm 4 \%$ ), since systems involved in fatty acid biosynthesis bear thiol groups in their active site. 2Hexadecynoyl-CoA and 2-octadecynoyl-CoA are structural analogues of 2-trans-hexadecenoyl-CoA and 2trans-octadecenoyl-CoA, two substrates of the InhA protein. These analogues are strong competitive inhibitors, versus enoyl-CoA substrates, of InhA activity (A. Quémard, J. S. Blanchard \& W. R. Jacobs, Jr, unpublished data). Addition of hexadecynoyl-CoA or of octadecynoyl-CoA at $43 \mu \mathrm{M}$, a concentration that totally abolishes InhA activity (unpublished data), inhibited the FAS-II activity by more than $90 \%$ (Fig. 3a), while it inhibited the de novo FAS-I activity only partially (by $52 \pm 4 \%$ ). Further evidence for the involvement of InhA in FAS-II activity was obtained by testing the effect of INH in the presence of $\mathrm{MnCl}_{2}$, which catalyses the activation of the drug (Zabinski \&
Blanchard, 1997). After a $3 \mathrm{~h}$ preincubation with fraction II, the activated INH inhibited the elongation reaction by $60 \%$ (Fig. 3a). The same inhibition rate was obtained for the test of INH on purified M. tuberculosis InhA under similar experimental conditions, after a $3 \mathrm{~h}$ preincubation (Zabinski \& Blanchard, 1997). In contrast, $\mathrm{Mn}^{2+}$-activated $\mathrm{INH}$ had no effect on FAS-I activity.

\section{Is FAS-II involved in mycolic acid biosynthesis?}

Data published by Banerjee et al. (1994) strongly suggested that InhA is involved in mycolic acid biosynthesis. Thus, it was important to characterize the involvement of this enzyme, and therefore of the FAS-II system, in this pathway. Mycolic acid biosynthesis has been shown to take place in a membrane-containing cell-wall fraction (Lacave et al., 1990). The presence of InhA in M. smegmatis cell-wall extracts was investigated by Western blot analysis, using purified anti-InhA antibodies, and a positive signal was observed (Fig. 1b). The action of InhA inhibitors on the biosynthesis of mycolic acids in a M. smegmatis cell-wall extract was then tested by following the incorporation of [1${ }^{14} \mathrm{C}$ ] acetate (Fig. 3). Both octadecynoyl-CoA and $\mathrm{MnCl}_{2}-$ activated INH inhibited the labelling of mycolic acids. A 30 min preincubation of the cell-wall extract in the presence of octadecynoyl-CoA was necessary to reach the level of inhibition observed for the FAS-II system. This is may be due to the low accessibility of enzymes in the insoluble cell-wall extract.

In parallel, the effect of octadecynoyl-CoA on mycolic acid biosynthesis by whole $M$. smegmatis cells was tested under the same conditions as for the cell-wall extract. Even after a $30 \mathrm{~min}$ preincubation in the presence of bacteria, octadecynoyl-CoA had absolutely no effect on the incorporation of $\left[{ }^{14} \mathrm{C}\right]$ acetate into either mycolic acids or the total alkali-labile lipidic compounds. This experiment showed that the activity of mycolic acid biosynthesis in our mycobacterial cell-wall extracts was completely independent of any potential presence of unbroken bacteria.

\section{DISCUSSION}

The picture of the course of action of INH against $M$. tuberculosis has long resembled a jigsaw puzzle, but important pieces have recently been added. We know that INH passively diffuses through the mycobacterial envelope (Bardou et al., 1998), is activated by $\mathrm{MnCl}_{2}$ (Zabinski \& Blanchard, 1997) and the catalase-peroxidase KatG (Quémard et al., 1996), possibly into an isonicotinoyl radical or anion, which then inhibits the InhA enzyme through covalent attachment to NADH within the active site of the protein (Rozwarski et al., 1998). InhA has been shown to preferentially catalyse the NADH-dependent reduction of 2-trans-enoyl-ACP molecules with 16 or more carbons (Quémard et al., 1995; Dessen et al., 1995). This reaction corresponds to the last step of fatty acid elongation. Furthermore, INH inhibits the biosynthesis of mycolic acids, which are 
extremely long fatty acids, specific to mycobacteria and related genera. Strong evidence suggests that this pathway is the primary target of INH (Takayama et al., 1972; Winder, 1982; Quémard et al., 1991). A link between the inhibition of InhA and the inhibition of mycolic acid synthesis is provided by the fact that a mutation in the inhA gene, which confers resistance to $\mathrm{INH}$, also leads to resistance of mycolic acid biosynthesis to INH (Banerjee et al., 1994). However, several pieces of the puzzle are still missing between InhA and mycolic acid synthesis. The present work allowed us to find one of these pieces.

We first sought for the presence of InhA in the known fatty acid biosynthesis complexes. The FAS-II system was the best candidate since it shares several important properties with InhA: specificity for relatively long chain substrates having $\sim 16$ carbons, and for ACP. Indeed, we have shown that InhA eluted in the mycobacterial protein fraction previously identified to contain FAS-II (Odriozola et al., 1977), the enzyme system that catalyses the malonyl-CoA and ACP-dependent elongation of palmitoyl-CoA into $\mathrm{C}_{18}-\mathrm{C}_{30}$ fatty acids. Furthermore, inhibition of this fatty acid synthesis by inhibitors of InhA activity, namely hexadecynoyl-CoA, octadecynoyl-CoA or $\mathrm{MnCl}_{2}$-activated $\mathrm{INH}$, strongly suggests that the InhA protein is part of the FAS-II system.

On the M. tuberculosis chromosome, the inhA gene forms an operon with the mabA gene, which probably encodes a $\beta$-ketoacyl-ACP reductase (Banerjee et al., 1994, 1998). The MabA protein most likely represents the other reductase of the FAS-II complex. Furthermore, in the reported M. tuberculosis genome sequence (Cole et al., 1998), three genes have been predicted as encoding a $\beta$-ketoacyl-ACP synthase; two of them, kas $A$ and $k a s B$, are adjacent to genes encoding ACP and a malonyl-CoA-ACP transacylase. Therefore, the KasA and KasB proteins most likely belong to a malonyl-CoAand ACP-dependent fatty acid biosynthesis system, and may catalyse the first step of the FAS-II system elongation cycle. KasA has been proposed to be an INH target in M. tuberculosis (Mdluli et al., 1998), on the basis of the detection of an interaction between INH and an ACP molecule, which is itself linked to KasA. However, neither direct interaction between KasA and INH nor inhibition of KasA activity by the drug have been shown.

Mycobacteria contain a number of fatty acid biosynthesis systems (Kolattukudy et al., 1997; Cole et al., 1998), a property reflected by the abundance and the great variety of unique lipids in their envelope. Bloch attempted to explain the presence in mycobacteria of several enzymic machineries providing straight-chain fatty acids by postulating that FAS-I and FAS-II act sequentially, FAS-I producing palmitoyl-CoA which is then transferred to FAS-II for further elongation (Bloch, 1977). One can imagine that the long-chain fatty acids produced by the FAS-II system serve as precursors for the formation of the meromycolic acids, which represent the $\mathrm{C}_{40}-\mathrm{C}_{60}$ main chain of mycolic acids. Indeed, the presence of the InhA protein in a mycobacterial cell-wall extract that synthesizes mycolic acids, and the fact that inhibitors of the InhA and FAS-II activities also inhibit mycolic acid synthesis strongly suggest that InhA and FAS-II participate in the mycolic acid pathway. Other experimental evidence favours the involvement of a fatty acid elongation system like FAS-II in the synthesis of the meromycolic chain (Winder, 1982). In particular, Qureshi et al. (1984) showed that a total soluble-protein extract from M. tuberculosis was able to incorporate radiolabelled palmitate in the presence of malonyl-CoA into saturated $\mathrm{C}_{18}-\mathrm{C}_{32}$ fatty acids but also into monounsaturated fatty acids bearing from 18 to more than 40 carbons. This suggests that a mycobacterial enzyme system may be able to further elongate the products of the FAS-II system, after introduction of a double bond. Also, the possibility remains that the FAS-II system, on its own, is able to synthesize molecules which have more than 30 carbons. Wheeler \& Anderson's work (1996) suggests that the INH-sensitive fatty acid elongation system involved in mycolic acid biosynthesis, therefore FAS-II, uses $(Z)$-tetracos-5-enoic acid as precursor.

After comparing the effects of antibiotic thiolactomycin on fatty acid elongation and on mycolic acid biosynthesis in M. smegmatis, the work of Slayden et al. (1996) led to the hypothesis that at least two ACPdependent elongation systems would be involved in the synthesis of mycolic acids, one INH-sensitive and one thiolactomycin-sensitive. However, the present work shows, in disagreement with the assumptions of Slayden et al., that the InhA-containing FAS-II system inhibited by INH, and which is involved in mycolic acid biosynthesis, is the FAS-II system described by Bloch (1977). It is difficult to come to a conclusion about the Slayden et al. experiments which were performed on a crude cytosolic fraction that contains several different fatty acid biosynthesis complexes, without any identification of the assayed elongation activity. Furthermore, the experimental conditions for the testing of INH on their crude extract, from which they conclude that FAS-II is not inhibited by INH, are not given.

Thus, the present work, as well as previous reports (Winder, 1982), leads to the conclusion that the FAS-II system described initially by Bloch is involved in mycolic acid biosynthesis, and that the antituberculosis drug INH prevents mycolic acid biosynthesis by inhibiting the FAS-II system activity. The precursors used by FASII are most likely supplied by the only de novo fatty acid synthetase known in mycobacteria, FAS-I. However, our knowledge of the mycolic acid biosynthetic pathway still remains incomplete. The following questions should be answered: (i) is FAS-II sufficient to elongate the chain to the final size of meromycolic chains $\left(\right.$ around $\mathrm{C}_{60}$ ); and (ii) what is the mechanism of introduction of double bonds into the meromycolic chain? Genes encoding the proteins responsible for the introduction of oxygenated functions (Dubnau et al., 1997) and cyclopropane rings (Dubnau et al., 1997; Yuan et al., 1995; George et al., 1995) into the meromycolic chain have been recently identified. Investigations into the properties of other 
enzymes necessary for building the complete backbone common to all types of mycolic acid will require the isolation of mutants defective in the mycolic biosynthesis pathway.

\section{ACKNOWLEDGEMENTS}

We are grateful to Dr Mamadou Daffé for helpful discussions. This work was supported by a doctoral fellowship (to H.M.) from the Fondation pour la Recherche Médicale, and by a grant $(98 \mathrm{~N} 92 / 0060)$ from the Direction des Relations Internationales $\mathrm{du}$ CNRS (Coopération internationale $\mathrm{CNRS} / \mathrm{NSF})$.

\section{REFERENCES}

Banerjee, A., Dubnau, E., Quémard, A., Balasubramanian, V., Um, K. S., Wilson, T., Collins, D., de Lisle, G. \& Jacobs, W. R., Jr (1994). $\operatorname{Inh} A$, a gene encoding a target for isoniazid and ethionamide in Mycobacterium tuberculosis. Science 263, 227-230.

Banerjee, A., Sugantino, M., Sacchettini, J. C., Jacobs, W. R., Jr (1998). The mabA gene from the inhA operon of Mycobacterium tuberculosis encodes a 3-ketoacyl reductase that fails to confer isoniazid resistance. Microbiology 144, 2697-2704.

Bardou, F., Quémard, A., Dupont, M. A., Horn, C., Marchal, G. \& Daffé, M. (1996). Effects of isoniazid on the ultrastructure of Mycobacterium aurum and Mycobacterium tuberculosis and on the production of secreted proteins. Antimicrob Agents Chemother 40, 2459-2467.

Bardou, F., Raynaud, C., Ramos, C., Lanéelle, M. A. \& Lanéelle, G. (1998). Mechanism of isoniazid uptake in Mycobacterium tuberculosis. Microbiology 144, 2539-2544.

Basso, L. A., Zheng, R., Musser, J. M., Jacobs, W. R., Jr \& Blanchard, J. S. (1998). Mechanisms of isoniazid resistance in Mycobacterium tuberculosis: enzymatic characterization of enoyl reductase mutants identified in isoniazid-resistant clinical isolates. J Infect Dis 178, 769-775.

Bloch, K. (1977). Control mechanisms for fatty acid synthesis in Mycobacterium smegmatis. Adv Enzymol 45, 1-84.

Cole, S. T., Brosch, R., Parkhill, J. \& 39 other authors (1998). Deciphering the biology of Mycobacterium tuberculosis from the complete genome sequence. Nature 393, 537-544.

Daffé, M. \& Draper, P. (1998). The envelope layers of mycobacteria with reference to their pathogenicity. Adv Microb Physiol 39, 131-203.

Dessen, A., Quémard, A., Blanchard, J. S., Jacobs, W. R., Jr \& Sacchettini, J. C. (1995). Crystal structure and function of the isoniazid target of Mycobacterium tuberculosis. Science 267, 1638-1641.

Dubnau, E., Lanéelle, M. A., Soares, S., Bénichou, A., Vaz, T., Promé, D., Promé, J. C., Daffé, M. \& Quémard, A. (1997). Mycobacterium bovis BCG genes involved in the biosynthesis of cyclopropyl keto- and hydroxy-mycolic acids. Mol Microbiol 23, 313-322.

Dubnau, E., Marrakchi, H., Smith, I., Daffé, M. \& Quémard, A. (1998). Mutations in the $c m a B$ gene are responsible for the absence of methoxymycolic acid in Mycobacterium bovis BCG Pasteur. Mol Microbiol 29, 1526-1528.

George, K. M., Yuan, Y., Sherman, D. R. \& Barry, C. E. (1995). The biosynthesis of cyclopropanated mycolic acids in $\mathrm{Myco-}$ bacterium tuberculosis. J Biol Chem 270, 27292-27298.

Harwood, J. L. (1986). Lipid metabolism. In The Lipid Handbook, pp. 485-525. Edited by F. D. Gunstone, J. L. Harwood \& F. B. Padley. London \& New York: Chapman \& Hall.

Kapur, V., Li, L. L., Hamrick, M. R. \& 10 other authors (1995). Rapid Mycobacterium species assignment and unambiguous identification of mutations associated with antimicrobial resistance in Mycobacterium tuberculosis by automated DNA sequencing. Arch Pathol Lab Med 119, 131-138.

Kikuchi, S. \& Kusaka, T. (1982). New malonyl-CoA-dependent fatty acid elongation system in Mycobacterium smegmatis. J Biochem 92, 839-844.

Kolattukudy, P. E., Fernandes, N. D., Azad, A. K., Fitzmaurice, A. M. \& Sirakova, T. D. (1997). Biochemistry and molecular genetics of cell-wall lipid biosynthesis in mycobacteria. Mol Microbiol 24, 263-270.

Lacave, C., Quémard, A. \& Lanéelle, G. (1990). Cell-free synthesis of mycolic acids in Mycobacterium aurum: radioactivity distribution in newly synthesized acids and presence of cell wall in the system. Biochim Biophys Acta 1045, 58-68.

Lanéelle, G. (1989). Mycolic acid metabolism: biosynthesis of complex lipids. Acta Leprol 7 (Suppl. 1), 65-73.

Mdluli, K., Slayden, R. A., Zhu, Y. Q., Ramaswamy, S., Pan, X., Mead, D., Crane, D. D., Musser, J. M. \& Barry, C. E. (1998). Inhibition of a Mycobacterium tuberculosis $\beta$-ketoacyl-ACP synthase by isoniazid. Science 280, 1607-1610.

Middlebrook, G. (1952). Sterilization of tubercle bacilli by isonicotinic acid hydrazide and the incidence of variants resistant to the drug in vitro. Am Rev Tuberc 65, 765-767.

Musser, J. M., Kapur, V., Williams, D. L., Kreiswirth, B. N., van Soolingen, D. \& van Embden, J. D. A. (1996). Characterization of the catalase-peroxidase gene $(k a t G)$ and inh $A$ locus in isoniazidresistant and -susceptible strains of Mycobacterium tuberculosis by automated DNA sequencing: restricted array of mutations associated with drug resistance. J Infect Dis 173, 196-202.

Odriozola, J. M. \& Bloch, K. (1977). Effects of phosphatidylcholine liposomes on the fatty acid synthetase complex from Mycobacterium smegmatis. Biochim Biophys Acta 488, 198-206.

Odriozola, J. M., Ramos, J. A. \& Bloch, K. (1977). Fatty acid synthetase activity in Mycobacterium smegmatis: characterization of the acyl carrier protein-dependent elongating system. Biochim Biophys Acta 488, 207-217.

Quémard, A., Lacave, C. \& Lanéelle, G. (1991). Isoniazid inhibition of mycolic acid synthesis by cell free extracts of sensitive and resistant strains of Mycobacterium aurum. Antimicrob Agents Chemother 35, 1035-1039.

Quémard, A., Sacchettini, J. C., Dessen, A., Vilchèzes, C., Bittman, R., Jacobs, W. R., Jr \& Blanchard, J. S. (1995). Enzymatic characterization of the target for isoniazid in Mycobaterium tuberculosis. Biochemistry 34, 8235-8241.

Quémard, A., Dessen, A., Sugantino, M., Jacobs, W. R., Jr, Sacchettini, J. C. \& Blanchard, J. S. (1996). Binding of catalaseperoxidase-activated isoniazid to wild-type and mutant $\mathrm{Myco-}$ bacterium tuberculosis enoyl-ACP reductases. J Am Chem Soc 118, 1561-1562.

Qureshi, N., Sathyamoorthy, N. \& Takayama, K. (1984). Biosynthesis of $\mathrm{C}_{30}$ to $\mathrm{C}_{56}$ fatty acids by an extract of Mycobacterium tuberculosis H37Ra. J Bacteriol 157, 46-52.

Ristow, M., Mohlig, M., Rifai, M., Schatz, H., Feldmann, K. \& Pfeiffer, A. (1995). New isoniazid/ethionamide resistance gene mutation and screening for multidrug-resistant Mycobacterium tuberculosis strains. Lancet 346, 502-503.

Rozwarski, D. A., Grant, G. A., Barton, D. H. R., Jacobs, W. R., Jr \& Sacchettini, J. C. (1998). Modification of the NADH of the 
isoniazid target (InhA) from Mycobacterium tuberculosis. Science 279, 98-102.

Shimakata, T., Fujita, Y. \& Kusaka, T. (1977). Acetyl-CoAdependent elongation of fatty acids in Mycobacterium smegmatis. J Biochem 82, 725-732.

Slayden, R. A., Lee, R. E., Armour, J. W., Cooper, A. M., Orme, I. M., Brennan, P. J. \& Besra, G. S. (1996). Antimycobacterial action of thiolactomycin: an inhibitor of fatty acid and mycolic acid synthesis. Antimicrob Agents Chemother 40, 2813-2819.

Snider, D. E., Raviglione, M. \& Kochi, A. (1994). Global burden of tuberculosis. In Tuberculosis: Pathogenesis, Protection, and Control, pp. 3-11. Edited by B. R. Bloom. Washington, DC: American Society for Microbiology.

Takayama, K. \& Qureshi, N. (1984). Structure and synthesis of lipids. In The Mycobacteria, a Source Book, vol. 1, pp. 315-344. Edited by G. P. Kubica \& L. G. Wayne. New York, NY: Marcel Dekker.

Takayama, K., Wang, L. \& David, H. L. (1972). Effect of isoniazid on the in vivo mycolic acid synthesis, cell growth, and viability of Mycobacterium tuberculosis. Antimicrob Agents Chemother 2, 29-35.

Wheeler, P. R. \& Anderson, P. M. (1996). Determination of the primary target for isoniazid in mycobacterial mycolic acid biosynthesis with Mycobacterium aurum $\mathrm{A}^{+}$. Biochem J 318, 451-457.
Winder, F. G. (1982). Mode of action of the antimycobacterial agents. In The Biology of the Mycobacteria, vol. 1, pp. 353-438. Edited by C. Ratledge \& J. Stanford. London: Academic Press.

World Health Organization (1997). Anti-tuberculosis drug resistance in the world: the WHO/IUATLD global project on antituberculosis drug resistance surveillance. Geneva: WHO Global Tuberculosis Programme.

Yasaka, Y., Tanaka, M., Shono, T., Tetsumi, T. \& Katakawa, J. (1990). 2-(2,3-Naphthalimino)ethyl trifluoromethanesulphonate as a highly reactive ultraviolet and fluorescent labelling agent for the liquid chromatographic determination of carboxylic acids. $J$ Chromatogr 508, 133-140.

Yuan, Y., Lee, R. E., Besra, G. S., Belisle, J. T. \& Barry, C. E. (1995). Identification of a gene involved in the biosynthesis of cyclopropanated mycolic acids in Mycobacterium tuberculosis. Proc Natl Acad Sci USA 92, 6630-6634.

Zabinski, R. F. \& Blanchard, J. S. (1997). The requirement for manganese and oxygen in the isoniazid-dependent inactivation of Mycobacterium tuberculosis enoyl reductase. J Am Chem Soc 119, 2331-2332.

Received 7 June 1999; revised 26 October 1999; accepted 3 November 1999. 